\title{
Water, power and culture in the Roman and Byzantine worlds: an introduction
}

\author{
Andrew Wilson
}

Received: 15 January 2012/Accepted: 20 January 2012/Published online: 28 March 2012

(C) Springer Science + Business Media B.V. 2012

Roman mastery of hydraulic engineering, and in particular of long-distance aqueduct supply systems, enabled the growth of a distinctive urban culture characterised by public bathing and lavish water display in both public and private settings. In the rural sphere, the extension of empire around the Mediterranean facilitated, among other things, the transfer of irrigation technologies between regions of different cultural and geological backgrounds. This led to an increasing flexibility of responses to irrigation problems, and to the development of complex schemes incorporating elements of several technologies; the growing complexity and scale of both urban water supply and rural irrigation systems required the development of legislation to regulate usage and protect the rights both of the state and of individual users of the systems. The provision, and the control, of water supply and irrigation systems, and of water-using amenities such as fountains, bath-houses and ornamental pools, became a powerful political tool for rulers and elites, courting favour with the populace for whom these structures were provided, asserting control over the resources necessary to construct them, and sometimes over nature itself, or emphasising status distinctions by the possession of display fountains, private baths, or private latrines in one's own house. The Roman Empire, and to a considerable extent also the Byzantine Empire which succeeded it in the east, was marked by the conscious manipulation of water resources for both usage and display, especially in the urban landscape.

The articles in this volume offer a variety of perspectives on the theme of water and power in the Roman and Byzantine Empires: legislation, control and management of urban water supply systems; administration of rural irrigation systems; the role of water-ways in the tax collecting system of Roman Egypt; and the extent to which various particularly Roman water technologies or habits were or were not adopted by subject population groups in the Near East. They derive from a workshop held at the University of Durham (UK) on 27-28 November 2009 on the theme of Water and Power: Hydraulic Management and Conflicts in the Ancient World, organised by Anna Leone and Tony Wilkinson (Department of Archaeology, Durham University) with Edmund Thomas (Department of Classics, Durham University). The workshop was sponsored by the Durham University Institute of

A. Wilson $(\bowtie)$

Institute of Archaeology, 36 Beaumont St, Oxford OX1 2PG, UK

e-mail: andrew.wilson@arch.ox.ac.uk 
Advanced Study, with funding also from the Rosemary Cramp Fund of Durham University and the British Academy. Five articles from the conference were published in Water History 2.2 (October, 2010), a special issue edited by Tony Wilkinson and entitled Ancient Near East and Americas, and more detail on the aims of the workshop is provided there (Wilkinson 2010). The six articles in this volume derive from the second day, focussing on the Roman and Byzantine worlds.

For much of the ancient world, and particularly for the ancient Near East, scholarly interest in the theme of water and power has typically concentrated on Wittfogel's (1957) model of Oriental despotism and hydraulic societies, in which the rise of a state bureaucracy is considered necessary for the development of complex irrigation systems linked to large river systems, and control of those irrigation systems reinforces or even underpins the power of the state. Wittfogel's model has attracted much criticism, although there is evidence to suggest that ancient empires certainly enabled the spread and development of irrigation technologies, though not necessarily through direct bureaucratic control; part of the purpose of the Durham workshop and of the articles in the previous special issue entitled Ancient Near East and Americas was to reassess the question from first principles (Wilkinson 2010; Wilkinson and Rayne 2010, pp. 116-117). For the Roman Empire, the issues are somewhat different, and the Wittfogel thesis never gained much traction in Roman studies. In Egypt, the Roman state certainly did take over the Pharaonic and Ptolemaic link between taxation levels and the performance of the Nile flood regime, and elsewhere, especially in the Near East, Spain and North Africa, very large irrigation schemes did exist, but they were very different from the Mesopotamian riverine models discussed by Wittfogel. Increasing personal wealth on the part of regional elites, and a stronger legislative and institutional framework, enabled the creation of complex irrigation networks which brought together numerous private individuals without the state acting as the driving force. A particularly striking example is revealed by the recent publication of a second-century AD irrigation law from Roman Spain, the so-called lex rivi Hiberiensis, governing a large irrigation scheme in the Ebro valley, whose main channel took water from the river Ebro and ran for at least $20 \mathrm{~km}$ (possibly much more), involving users from three administrative communities or pagi belonging to two different municipalities (Beltrán Lloris 2006). The preserved parts of the law stipulate the duties of maintenance incumbent upon users of the system proportional to the amount of water they received, and regulate the procedures for managing conflict or disputes, in a council composed of the users of the system who exercised votes in proportion to their share of water rights. The council also met annually to decide on the irrigation schedule for the following year. Not all Roman irrigation schemes, however, were such large-scale ventures; they run the full spectrum between small, local systems and extensive regional schemes. A large number of medium-length channel and qanat systems were developed in the Roman and Byzantine Syria, often organised at the level of local communities, either towns or villages (Braemer et al. 2010; Wilkinson and Rayne 2010, pp. 122-123). This variety, coupled with the Roman-period development and spread of Hellenistic mechanical water-lifting technologies, enabled the colonisation of new lands by smaller entities than the state, bringing irrigation technology within the reach of smaller farmers (Wilson 2002, pp. 7-9; 2003). The long verse inscription on the Mausoleum of the Flavii at Kasserine in Tunisia proclaims, among other things, that T. Flavius Secundus was the first to introduce irrigated viticulture to the region (CIL 8.211 lines 51-53). For the majority of such systems, the involvement of the state was principally through providing the institutional and legal framework to protect property and water rights and to resolve conflict. In some cases, the state also provided institutional incentives encouraging the development of marginal lands, 
including through irrigation schemes, with a view to maximising revenues from taxes or from rents on imperial estates (Kehoe 1988; Hitchner 1995; Leone this volume).

Much has been made of the symbolic effect of Roman aqueducts and their long arcades striding across the rural landscape. The provision of such monumental artificial water courses was expensive, and advertised the resources and power of the funder-whether the emperor, a city council or a private individual; or, more generally, the achievements of Roman culture and power in dominating and controlling nature for human benefit (Frontinus, aq. 1.1; Purcell 1996; for an overview of the technology, see Wilson 2008). The fabric and infrastructure of urban water supply might be used to convey messages about a city's status and its relations with wealthy and even imperial benefactors. The large population concentrations of many Roman cities were unsustainable without the external water supply brought in by aqueducts, and their provision was a matter of political concern. But urban aqueducts also ushered in a new and especially Roman way of life, which went beyond the mere provision of (relatively) clean water for drinking, washing and other uses: public fountains became a part of the urban landscape; communal bathing in public baths became a part of the daily routine; public latrines flushed by running water could be built; and private individuals increasingly used ornamental pools and fountains within their houses as expressions of status (Wilson 1995, 1997, pp. 145, 159-168; Jones and Robinson 2005).

The Romans were not of course the first to use large-scale hydraulic works as a vehicle for advertising royal or imperial power: Sennacherib's aqueduct inscriptions at Nineveh and Jerwan proclaim this message loudly (Wilkinson and Rayne 2010, p. 121), and tyrants in Archaic Greece had used the construction of public water supplies to bolster their political support-Polycrates of Samos, Theagenes of Megara, and the Peisistratids at Athens (Wilson 2008, pp. 293-294). But Imperial building projects in Rome were shot through with messages of power that were underscored by the manipulation of natural and artificial water sources to an unprecedented degree. Augustus, in addition to several aqueducts, built a naumachia or artificial lake for sea-battles. Nero's creation of an ornamental lake among the grounds of his Domus Aurea, using the overflow from the monumental nymphaeum below the Temple of Divus Claudius, was a statement of his ability to control water and fashion landscapes, creating, literally, a rus in urbe. Vespasian's suppression of the lake, not merely filling it in but also building the Amphitheatrum Flavium (the Colosseum) on its site, was an equally potent statement of power, distancing the new dynasty from the excesses of Nero's rule. As Jim Crow points out in this volume, Byzantine emperors in the fifth century $\mathrm{AD}$, following the construction of new aqueduct lines, reserved the water from the original Hadrianic aqueduct to serve the imperial palace, the public baths and the fountains at Constantinople, forbidding private uses from this line. Imperial financing of major aqueducts and large public baths in cities in many Roman provinces extended this message to other regions of the empire, although local communities also funded such projects, and, increasingly in the second century and early third century $\mathrm{AD}$, very wealthy individuals donated public buildings including aqueducts, fountains, baths (but also temples, theatres and other structures) to their home towns, often as part of a competition for holding public office. The promise of a running water supply or a new set of baths could be an extremely powerful argument in a campaign for election to a powerful civic magistracy.

The development of complex urban supply systems and irrigation networks posed increasingly complicated problems of management. We are fortunate to have a work written by the administrator of Rome's aqueduct network in the early years of the reign of Trajan, c. AD 100, the curator aquarum Sextus Iulius Frontinus, whose treatise on the 
aqueducts of Rome, De aquaeductu urbis Romae, gives illuminating and sometimes puzzling insights into the administration of the city's nine aqueducts (at the time he wrote), some of the laws governing their use, and the problems of fraud he uncovered among the waterworks staff, who were found to be selling undeclared grants of water on the side. Frontinus makes it clear that all private connections to Rome's aqueduct network had to be sanctioned by imperial permission, but as Bruun's article in this volume shows, that was by no means the case in other cities, where aqueduct systems were administered at a municipal level. Roman law had to evolve to cater for the various eventualities created by the construction and maintenance of long-distance supply lines, which often needed to cross existing properties and estates, and to regulate the different rights and interests of property owners, users of the water, and the owner of the aqueduct system, whether this was the state, a municipality, or a private individual. An overview of much of the evidence on Roman water legislation is given by Bruun (2000), but the more recent publication of the lex rivi Hiberiensis (Beltrán Lloris 2006) shows how much more there is still to be learned. Brent Shaw (1984) argued that the Romans never really developed a coherent body of water legislation to govern indigenous or pre-Roman irrigation systems that Rome encountered in, for example, its North African provinces. In a sense, this poses the problem in the wrong way; systematic codification of Roman law came late, only becoming comprehensive under Justinian in the sixth century. Roman law was reactive and developed through case law, adjudicating on new problems, the judgements on which set precedent for future cases. Already by the late Republic, Roman water law was sufficiently extensive and complex that Cicero consulted Marcus Tugio, a jurist who specialised apparently in water law, in a dispute involving water rights for an irrigated flower garden at his villa at Tusculum, which appears to have concerned water derived from a stream or aqueduct known as the Aqua Crabra (Cicero, pro Balbo 20; cf. Bannon 2009, pp 137-141). There was no one-size-fits-all legislation; rather, it adapted to circumstances, and the Roman legal system was capable of creating special water laws for particular systems, such as the lex rivi Hiberiensis in the Ebro valley, or recording the adjudications of disputes on public inscriptions such as the third-century AD Lamasba irrigation decree from Algeria $(I L S 5793=$ CIL $8.18587=4440$; De Pachtère 1908; Shaw 1982; Meuret 1996). Anna Leone's article in this volume argues that Roman property and water law was perfectly able to accommodate indigenous irrigation practices encountered in North Africa.

The existence of an aqueduct offered new ways in which the rich might express their status by material display in urban contexts. In Rome, imperial permission was needed for a private water grant; the corollary was that possession of a private connection to one's house in Rome indicated, even advertised, that one had received this beneficium from the emperor. Elsewhere, permission was usually granted by the relevant town council (Bruun, this volume). Water connections had to be paid for, or were granted exceptionally as a civic honour. Q. Paconius Lepta, the friend of Cicero (or the son of his friend) was granted a private water connection to his house by the town council of Cales in the mid/late first century $\mathrm{BC}$, on the occasion of his election to a civic magistracy (the quattuorvirate) and in return for unspecified benefactions (CIL X $4654=I L S 5779)$. At Suessa Aurunca in AD 193, a prominent freedman and priest of the imperial cult (augustalis), C. Titius Chresimus, who had funded a gladiatorial show, was granted honours including a private water connection, 'as if he were a member of the town council', implying therefore that the councillors of Suessa also received this privilege (CIL X $4760=I L S$ 6296; Corbier 1984, p. 267). But those who paid for running water to their houses often did so not primarily to get better quality water for drinking, but to get greater quantities of sometimes non-potable water, which was used for monumental pools, fishponds and gardens. This made for 
pleasant surroundings, but it was also highly visible to visitors and guests; an ostentatious display of status and power (Wilson 1995; Jones and Robinson 2005). This is as true for country villas as it is for elite town houses.

In North Africa, the technological legacy of Rome in the field of hydraulic engineering lasted through the Vandal and Byzantine periods, although with some indications of a decline in the number of public works that were maintained, in the face of changing social and economic conditions. The Ostrogothic kings in Italy ordered repairs to aqueducts and urban drains, and this was partly a self-conscious attempt to underpin their authority by demonstrating their ability to maintain a characteristically Roman style of urban living (Wilson 2000, pp. 177-178; Cassiodorus Variae III 30; VIII 29-30). In the rest of the western Mediterranean the ability of post-Roman states to maintain aqueduct systems, let alone develop new ones, was very limited; early medieval cities with newly constructed aqueducts like Reccopolis in Spain (founded AD 578) are extremely rare exceptions, intended to make a bold and powerful statement about the ruler's very Roman style of power. Generally in the west, as Roman aqueduct systems fell into disrepair, flowing water supply and even sewerage networks became the preserve of monasteries-communities with enough central authority to plan, control and manage the physical infrastructure of their institution and environment (Wilson 2000, pp. 177-178). Complex hydraulic technologies persisted for longer in the eastern Mediterranean, where Roman power remained in the guise of the Byzantine Empire, and indeed in the early centuries of Byzantium the water supply of the new capital took Roman water supply technology, quite literally, to new lengths, creating the longest aqueduct lines and the biggest reservoir cisterns of the ancient world (Crow et al. 2008; Crow this volume). Some of these technologies even passed into the Ottoman Empire following the fall of Constantinople in 1453.

The articles in this volume address various aspects of some of the above themes. Christer Bruun examines the evidence for the administration of grants of the right to draw water from public aqueducts and watercourses, arguing that while the emperor's permission was indeed required to draw water from the aqueduct network supplying Rome, the idea sometimes expressed that this was the case also for other cities throughout the empire is a simple and uncritical extrapolation from Frontinus, and there is good evidence that such grants of water rights were handled by local civic authorities. Even in cases where an aqueduct had been paid for by imperial benefaction, the administration and the costs of upkeep were devolved to local authorities. More generally, he provides an overview of legislation on the administration of aqueducts and public water sources. Particularly noteworthy are the indications that the late Roman state, apparently struggling with the costs of maintaining aqueduct systems, sought to pass on much of the burden of maintenance to landowners through whose properties the aqueducts ran. There were also a number of legal provisions regulating the drawing of water from rivers, including the principle that navigation along rivers should not be interfered with by the drawing-off of excessive water for irrigation; a rescript of Marcus Aurelius and Lucius Verus also affirmed the principle that water from a river allocated for irrigation should be proportional to the size of the fields to be irrigated, which may resonate with the principles of proportionality seen in the earlier lex rivi Hiberiensis.

Jim Crow extends the perspective into the Byzantine period, tracing the development of administrative structures and legislation to manage the increasingly complex and ambitious water systems of the new capital, Constantinople. He highlights how in many respects the model of the aqueduct network at Rome was followed, sometimes developing Roman techniques to new heights. The early Byzantine aqueducts of Constantinople were astonishing feats of engineering which exceeded even the longest Roman aqueducts - the first 
phase lines totalled $268 \mathrm{~km}$, and the second phase $451 \mathrm{~km}$-and discharged into vast reservoir cisterns, necessitated both by the need to balance the seasonally variable discharge from karstic springs, and also by the desire to provide a reserve against siege. However, the fourth- and fifth-century prohibitions on the use of aqueduct water to irrigate suburban farmland or drive water-mills in or around Constantinople seem to stand in contrast to the situation in the suburbs of Rome a few centuries before (cf. Wilson 1999). To meet the costs of upkeep of the aqueducts, from the fifth century onwards fees of 100 gold pounds paid by the consuls at the start of their office were hypothecated to the maintenance of the water system; the relevant legislation expresses the idea that the support thus provided by the consuls for the public water supply is a more lasting way of gaining public support than was the former practice of scattering coins among the people. By the late twelfth century, however, the Byzantine state was unable to keep repairing the great aqueduct bridges of the long-distance systems from Thrace, and the city's water supply relied on the sources that had fed the closer Hadrianic aqueduct, with the result that the city then received less water, and no longer above the $c .30-35 \mathrm{~m}$ contour.

The next two articles turn from legislation and administration to issues of water use and power relations in society. Edmund Thomas analyses the use of water fountains and display in the architecture of the 'Villa Claudia' at Anguillara Sabazia northwest of Rome. He convincingly re-dates this terraced villa, with its extraordinary elliptical monumental fountain or nymphaeum, which has previously been considered of Republican date, to the Augustan period, and argues that the water display features must have been fed from the Aqua Alsietina which ran through the region. He suggests that the architecture of the nymphaeum deliberately recalls the elliptical shape of Augustus' naumachia (arena for naval battles) in Rome, which was completed in $2 \mathrm{BC}$ and fed by the Aqua Alsietina, and he further speculates whether the owner, one of the Cornelii (several of whom became consuls), might have been curator aquarum in charge of Rome's aqueduct network between $\mathrm{AD} 8$ and 13. Irrespective of the identity of the owner, and the possible architectural link with water display at Rome itself, what is clear is that lavish water display architecture on this scale was unusual at this relatively early date even in high-status villas, and the nymphaeum of the 'Villa Claudia' makes a strong and bold statement about the owner's wealth and command of resources.

Zena Kamash's exploration of the relationship between shifting power, changing behaviour and new water technologies in the Roman Near East identifies a number of respects in which particularly Roman technologies and practices of water usage were either not adopted or were adopted only in a limited and late fashion in the Near East, and this sheds light on the question of the extent to which empires, deliberately or otherwise, fostered the spread of hydraulic technology. She argues that the success or failure of particular technologies was governed by social and cultural factors. There does seem to be a Roman-period development in dam technology, with the creation of stepped air faces which gave greater strength and allowed bigger dams to be built, retaining larger bodies of water for irrigation. Some other technologies, however, were not so widely adopted as they were elsewhere in the Roman Empire. The uptake of lead pipes for urban distribution systems and domestic supply was limited, and ceramic pipes continued to be widely used; lead pipes are found chiefly in the cities of colonial status or with strong Roman cultural links, and this may reflect the habits of artisans or the supervisors of water supply projects in those cities. The use of display fountains, both public nymphaea and domestic fountains, appears more restricted in the Near East than in other parts of the Roman world, including Asia Minor and North Africa. Here the explanation may be a desire to conserve scarce resources, but there may also be a cultural element: the home was considered a more 
private space and was thus less used as a place to impress visitors. More surprising at first sight is the apparent initial resistance to the spread of the public bathing habit, and of latrines. Public baths only became common in the third century, and even then the pools were often smaller than those in other regions of the Roman world, for which the explanation may be a combination of a desire to conserve water and a local tradition of greater modesty about public nudity. Kamash argues that the rarity of public latrines in the Roman Near East outside Syria was a result of Jewish law, which prohibited the discharge of excrement into running water; again, where latrines are found in Judaea, it is in the more consciously Roman cities such as Caesarea and Scythopolis. The divergent trajectories of uptake of different features of Roman water technology illustrate how technological change is closely dependent on social practice, and may differ between different cultural groups within the same society.

Penelope Wilson's article on the northwest Nile Delta takes a different angle, exploring how the settlement pattern of the region was affected by the needs of the Ptolemaic, Roman and Byzantine states to control the collection of agricultural surpluses of tax, via nodal points on the inland waterways used for transport. Increasing settlement density in the Ptolemaic and Roman periods was probably due to the foundation of Alexandria, but successful management of the Delta landscape required the creation of a system of canals to regulate Nile flow and lagoon discharge and link the Nile distributaries and lagoons to each other and to the sea, to create a better transport network. Sites clustered along the lines of canals or the Nile channels, or around the edges of lagoons such as Lake Mareotis, which provided an easy means of water transport to ship surplus agricultural production, including wine, to the market at Alexandria. The larger sites were administrative centres which acted as nodal points to control or monitor the distribution of goods and of tax revenues, such as the customs post at Schedia. This was a significant change from the earlier, Pharaonic, settlement pattern, and persisted in broad outline until the twentieth century when the advent of the railways and better roads changed the nature of the regional transport system, and the balance of power shifted to new administrative centres linked to these new routes.

Anna Leone re-examines Brent Shaw's judgements (1984) on the extent to which Rome introduced new irrigation technologies to North Africa, focussing on a comparison of the two sets of evidence from late antique North Africa: the Kasserine Survey, directed by Bruce Hitchner in the 1980s, and the late fifth-century Vandal documents known as the Albertini Tablets, which document the sale of plots of land with trees and irrigation infrastructure. She develops Hitchner's (1995) earlier comparison of these two datasets to illustrate the imbrication of possibly pre-Roman systems of water management and irrigation, and property rights under the Roman law. While the upland terracing systems in the Kasserine survey may reflect indigenous practices, their development in the area only occurs from the third century AD onwards, and seems to have been incentivised by the Roman legal instruments which encouraged the development and cultivation of the previously unused land in return for certain rights over it. Similarly, in the Albertini Tablets some of the technical terms for plots of land and irrigation infrastructure seem to derive from indigenous rather than Roman terms, and the practice of assessing plots of land by the number of trees on them may also be pre-Roman, but the landholding rights and their sale seems to take place within a framework of Roman law that persisted well into the Vandal period.

The articles from the Durham workshop indicate something of the variety of ways in which one might approach the theme of water and power as it relates to the Roman and Byzantine Empires-not only the differing ways in which the state might administer urban 
water supply and rural irrigation systems, and control their distribution, but also the ways in which power relations might be expressed through command, benefaction and use of water systems and the display of water features. While empires can clearly act as vehicles for spreading hydraulic technologies-and the Roman Empire shows in a number of respects a striking commonality of hydraulic technology between widely separated provinces - their administration also needs to be able to adapt to local practices and conditions, and the varying religious and cultural backgrounds of different social groups may influence the extent and the manner in which these technologies are adopted.

\section{References}

Bannon CJ (2009) Gardens and neighbors; private water rights in Roman Italy. University of Michigan Press, Ann Arbor

Beltrán Lloris F (2006) An irrigation decree from Roman Spain: The Lex Rivi Hiberiensis. J Rom Stud 96:147-197

Braemer F, Geyer B, Castel C, Abdulkarim M (2010) Conquest of new lands and water systems in the western Fertile Crescent (Central and Southern Syria). Water Hist 2:91-114

Bruun C (2000) Water legislation in the ancient world. In: Wikander Ö (ed) Handbook of ancient water technology. E. J. Brill, Leiden, pp 537-604

Corbier M (1984 [1985]) De Volsinii à Sestinum: cura aquae et évergétisme municipal de l'eau en Italie. Revue des études latines 62:236-274

Crow J, Bardill J, Bayliss R (2008) The water supply of Byzantine Constantinople. Society for the Promotion of Roman Studies, London

De Pachtère F-G (1908) Le règlement d'irrigation de Lamasba. Mélanges de l'École française de Rome, Antiquité 28:373-400

Hitchner RB (1995) Historical text and archaeological context in Roman North Africa: the Albertini Tablets and the Kasserine Survey. In: Small DB (ed) Methods in the Mediterranean. Historical and archaeological views on texts and archaeology. E. J. Brill, Leiden, pp 124-142

Jones R, Robinson D (2005) Water, wealth and social status at Pompeii: the House of the Vestals in the first century. Am J Archaeol 109(4):695-710

Kehoe DP (1988) The economics of agriculture on imperial estates in Roman North Africa. Vandenhoeck and Ruprecht, Göttingen

Meuret C (1996) Le règlement de Lamasba: des tables de conversion appliquées à l'irrigation. Antiq Afr 32:87-112

Purcell N (1996) Rome and the management of water: environment, culture and power. In: Shipley G, Salmon J (eds) Human landscapes in Classical Antiquity: Environment and culture. Routledge, London, pp 180-212

Shaw BD (1982) Lamasba: an ancient irrigation community. Antiq Afr 18:61-103

Shaw BD (1984) Water and society in the ancient Mahgrib: technology, property and development. Antiq Afr 20:121-173

Wilkinson TJ (2010) Introduction. Water Hist 2:85-90

Wilkinson TJ, Rayne L (2010) Hydraulic landscapes and imperial power in the Near East. Water Hist 2:115-144

Wilson AI (1995) Running water and social status in North Africa. In: Horton M, Weidemann T (eds) North Africa from antiquity to Islam. Centre for Mediterranean Studies (University of Bristol), Bristol, pp 52-56

Wilson AI (1997) Water management and usage in Roman North Africa: a social and technological study. D. Phil. Thesis, University of Oxford

Wilson AI (1999) Deliveries extra urbem: aqueducts and the countryside. J Roman Archaeol 12(1):314-331

Wilson AI (2000) Drainage and sanitation. In: Wikander Ö (ed) Handbook of ancient water technology. E. J. Brill, Leiden, pp 151-179

Wilson AI (2002) Machines, power and the ancient economy. J Rom Stud 92:1-32

Wilson AI (2003) Classical water technology in the early Islamic world. In: Bruun C, Saastamoinen A (eds) Technology, ideology, water: from Frontinus to the Renaissance and beyond. Inst Rom Finl, Roma, pp 115-141 
Wilson AI (2008) Hydraulic engineering. In: Oleson JP (ed) Handbook of engineering and technology in the classical world. Oxford University Press, Oxford, pp 285-318

Wittfogel KA (1957) Oriental despotism: a comparative study of total power. Yale University Press, London

\section{Abbreviations}

$C I L=$ Preussische Akademie der Wissenschaften (1862-) Corpus Inscriptionum Latinarum. G. Reimer/W. de Gruyter, Berlin

$I L S=$ Dessau H (ed) (1954-1955) Inscriptiones Latinae Selectae. Weidmann, Berlin

\section{Author Biography}

Andrew Wilson is Professor of the Archaeology of the Roman Empire at the University of Oxford, and a Fellow of All Souls College, Oxford. His research interests include the economy of the Roman Empire, ancient technology, ancient water supply and usage, Roman North Africa and archaeological field survey. He has served as Chairman of the Society for Libyan Studies, and has excavated and studied ancient water systems in Italy, Tunisia, Libya, Syria, Cyprus and Morocco. 